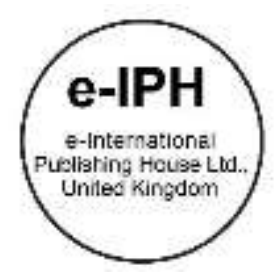

\title{
Parallel Glueline of Withdrawal Capacity for Mengkulang Glulam
}

\author{
Rohana Hassan ${ }^{1}$, Nor Jihan Abd Malek², Mohd Nizam Shakimon³, Mohd Sapuan Salit ${ }^{4}$ \\ ${ }^{1}$ Fellow Researcher, Institute for Infrastructure Engineering and Sustainable Management (IIESM), Universiti Teknologi MARA, 40450 \\ Shah Alam, Selangor, Malaysia \\ 2SEGi University, No 9, Jalan Teknologi, Taman Sains Selangor, Kota Damansara, PJU 5, 47810 Petaling Jaya, Selangor Darul \\ Ehsan, Malaysia \\ ${ }^{3}$ Faculty of Engineering \&Technology Infrastructure, Infrastructure University Kuala Lumpur (IUKL), Unipark Suria, Jalan Ikram-Uniten, \\ 43000 Kajang, Selangor Darul Ehsan, Malaysia. \\ 4Laboratory of Biocomposite Technology Institute of Tropical Forestry and Forest Products (INTROP), Universiti Putra Malaysia, \\ 43400 Serdang, Selangor, Malaysia
}

rohan742@uitm.edu.my, jihanmalek@segi.edu.my, nizam@iukl.edu.my, sapuan@upm.edu.my

Tel:: +60196963491

\begin{abstract}
The failure modes and load-carrying capacity of timber connection can be predicted using European Yield Model (EYM). In the load-carrying capacity formula, an unknown parameter for Mengkulang Glulam with the bolt as a fastener, is the withdrawal capacity, $F_{a x, R k}(k N)$. In this research, the withdrawal capacity tests were conducted with respect to the difference in bolt diameter and glue line existences. The results showed the larger diameter $18 \mathrm{~mm}$ parallel with the glue line giving the highest withdrawal capacity and resistance when compared to the same diameter without glue line and $14 \mathrm{~mm}$ diameter with and without the glue line.
\end{abstract}

Keywords: Engineered Wood Product (EWP); Structural Material; Withdrawal Capacity; European Yield Model (EYM)

eISSN: 2398-4287@ 2021. The Authors. Published for AMER ABRA cE-Bs by e-International Publishing House, Ltd., UK. This is an open access article under the CC BYNC-ND license (http://creativecommons.org/licenses/by-nc-nd/4.0/). Peer-review under responsibility of AMER (Association of Malaysian Environment-Behaviour Researchers), ABRA (Association of Behavioural Researchers on Asians/Africans/Arabians) and CE-Bs (Centre for Environment-Behaviour Studies), Faculty of Architecture, Planning \& Surveying, Universiti Teknologi MARA, Malaysia.

DOI:

\subsection{Introduction}

Timber is one of the first materials used in construction. Nowadays, modern prestige's scientific and technical developments succeed by inventing new construction materials such as cement, concrete, steel, and reinforcement concrete. It took a lot of time, effort, and money to develop and improve the work of these materials to obtain residential buildings and installations, industrial and commercial requirements of new investment. Nonetheless, timber still plays a vital role as a material in the construction industry. For engineering purposes, the best suitable selection of a specific type of timber is essential to take advantage of the best efficiency. One of the international achievements of engineered timber product (ETP) made of Malaysian tropical timber was designed during the exposition held in Milano Italy (Fig. 1).

Although the use of timber in construction is rapidly increasing, there is a dearth of information about tropical timber. Lack of engineering information for engineered wood product manufactured from tropical timber has made this study crucial. There have been few investigations on mechanical qualities such as pullout resistance parallel for Mengkulang glulam, and the majority of previous studies focused on withdrawal resistance of fasteners other than bolts, primarily nails or screws.

eISSN: 2398-4287@ 2021. The Authors. Published for AMER ABRA cE-Bs by e-International Publishing House, Ltd., UK. This is an open access article under the CC BYNC-ND license (http://creativecommons.org/licenses/by-nc-nd/4.0/). Peer-review under responsibility of AMER (Association of Malaysian Environment-Behaviour Researchers), ABRA (Association of Behavioural Researchers on Asians/Africans/Arabians) and cE-Bs (Centre for Environment-Behaviour Studies), Faculty of Architecture, Planning \& Surveying, Universiti Teknologi MARA, Malaysia. DOI: 


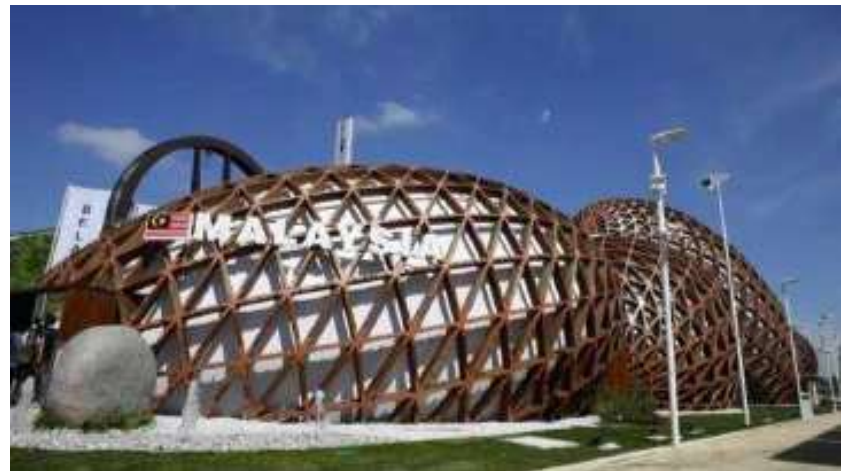

Malaysian Pavillion Expo Milano 2015 (Source: http://www.mtib.gov.my).

The choice of the timber species depends on its engineering properties, such as mechanical and physical properties. Many experimental works on Mengkulang glulam capabilities have been assembled due to the acceptable features of Mengkulang to be designed as glulam product. Mengkulang, one of the Malaysian light timbers of Heritiera spp "botanical name", family of sterculiacer, classified as medium wood, normal colour is brown, and the heartwood is usually darker in colour than the sapwood (CIRAD, 2009).

The previous studies reported on Mengkulang species are such as; shear block test performance (Abd. Malek et al. 2019); pull-out strength of steel rods bonded at five different angles to the grain (Mohamad et al. 2018); comparison of bolt withdrawal capacity (Abd. Malek, et al. 2016a and 2020) and perpendicular dowel-bearing strength properties without glue line (Abd. Malek et al. 2016b). In order to further enhancing the research development on Mengkulang species; this study focuses on the determination and comparison of the withdrawal capacity of $14 \mathrm{~mm}$ and $18 \mathrm{~mm}$ diameter bolts for parallel grain directions. The objective of the study is to determine the engineering effect of bolts withdrawal on surface having with and without glue line of the Mengkulang glulam, respectively.

\subsection{Glued Laminated Timber}

Glued laminated (glulam) timber is a structural engineered wood product produced by assembling individual timber pieces with thickness not exceeding 40mm (MS 758, 2001). The glulam development process includes different production stages (Fig. 1).

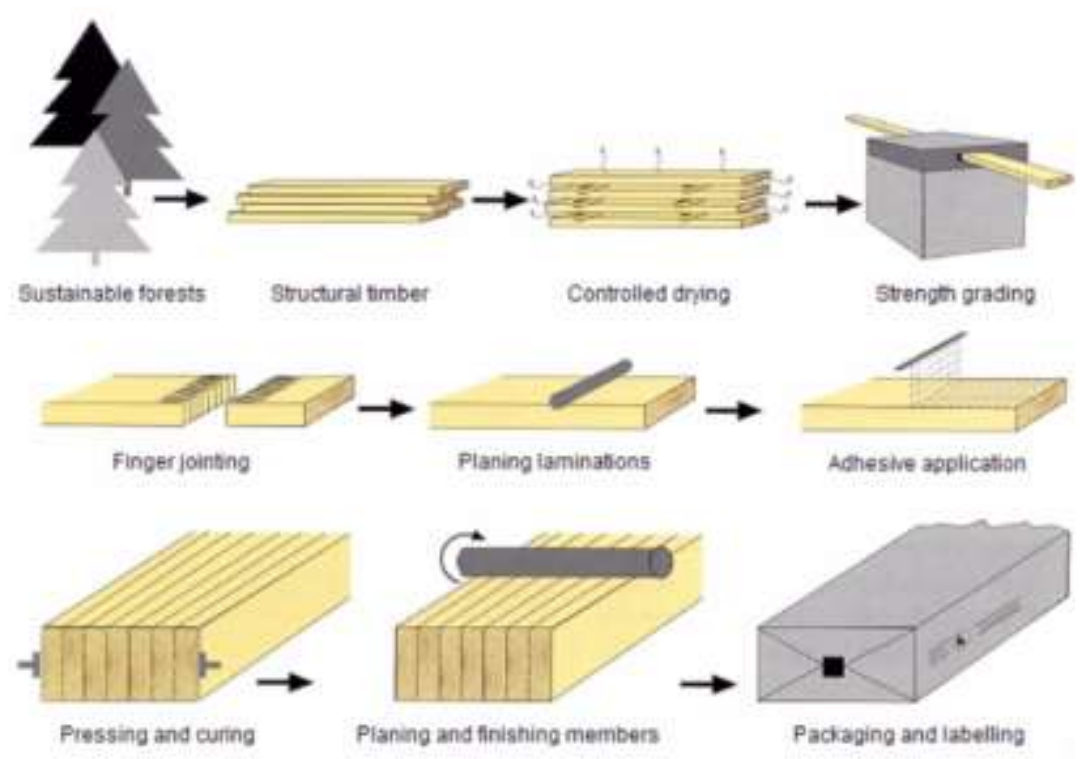

Fig. 1: Stages of manufacturing glulam (Manufacturing process of glulam, n.d.)

The first stage includes kiln-drying of sawn timber to achieve a moisture content of 8 to $15 \%$ for untreated timber pieces and between 11 to $18 \%$ if the pieces are treated with preservatives. The moisture content difference between the pieces should not be more than 5 $\%$, preventing large moisture gradients that may later affect the bonding (BS EN 14080, 2013; MS 758, 2001). Glued-laminated timber has higher allowable design values compared to solid timber. Previous research has shown that glulam and other ETPs are stronger than their parent material (H'ng, 2003 and Wan Mohamad et al., 2011). The best properties of the glued-laminated timber are manufacturing design can resist stresses during bending, curved, tapered members or axial because of the unique way of placing higher grade laminations where strength is essential (Moody \& Hernandez, 1997). The Glulam timber arches, beams and curves can span or spread large spaces without the need for intermediate columns, and that is because of the excellent stiffness and the high strength of the Glulam timber. Thus, it allows better design elasticity to compare with another type of timber (Marutzky, 2002). 
Based on Hereford, (2012), there are many benefits of nails to be selected for timber connection application because of no requirements of technical skills it is easy for installation, nails compared to other fasteners very economical due to low cost in the market. A bolt is an externally threaded length fastener manufactured and designed for driven into holes in assembled member parts and is usually intended to be tightened or released by torquing a nut. Bolts showed a perfect framing connection, which has high critical strength.

Both shear strength and withdrawal resistances in bolts are much better compared to screws and nails; therefore, the assembled connection would not show detached under strain (Schuttner, 1997). Hamid et al. (2012) defined withdrawal resistance as the amount of resistance to withdrawal force in a plane normal to the face. It is impacted by the density and internal bonding of the panel. Withdrawal capacity is influenced by the engineering properties of fastener, shape and sizes of mechanical fastener, the surface situation of the fastener and timber, speed rate of withdrawal, grain direction, condition of the pre-drilled hole of the wood, depth of penetration and wood density (ASTM D1761-12, 2012).

\subsection{Methodology}

The main objective of this research is to determine the withdrawal capacity of bolt diameter of $14 \mathrm{~mm}$ and $18 \mathrm{~mm}$ on Mengkulang glulam, loaded parallel with or without the glue line. The experimental tests were conducted at UiTM in a heavy structure laboratory at the School of Civil Engineering, Shah Alam. The universal testing machine (UTM) were used to perform the withdrawal capacity test. The design of block sample materials were according to EC5: 2008 (Table 1) and ASTM D1761-12 2012 standards. In this research, the bolt diameters are $14 \mathrm{~mm}$ and $18 \mathrm{~mm}$ with half-threaded of $45 \mathrm{~mm}$ galvanized steel bolt were used. The Mengkulang glulam was cut into 20 blocks specimens with $140 \mathrm{~mm} \times 130 \mathrm{~mm} \times 90 \mathrm{~mm}$ dimension parallel to the grain. Five (5) blocks each for with and without glue line. The position of the minimum spacing and edge distance is as in Fig. 2.

Table 1: Minimum values of spacing of edge and end distance for steel bolts.

\begin{tabular}{ccc}
\hline $\begin{array}{c}\text { Spacing and } \\
\text { end/edge distances }\end{array}$ & Angle & $\begin{array}{c}\text { Minimum spacing or } \\
\text { distance }\end{array}$ \\
\hline $\mathrm{a}_{1}$ (parallel to grain) & $0^{\circ} \leq \alpha \leq 360^{\circ}$ & $(4+\mid \cos \alpha) \mathrm{d}$ \\
$\mathrm{a}_{2}$ (perpendicular to & $0^{\circ} \leq \alpha \leq 360^{\circ}$ & $4 \mathrm{~d}$ \\
grain) & $-90^{\circ} \leq \alpha \leq 90^{\circ}$ & $\max (7 \mathrm{~d} ; 80 \mathrm{~mm})$ \\
$\mathrm{a}_{3,1}$ (loaded end) & $90^{\circ} \leq \alpha \leq 150^{\circ}$ & $\max [(1+6 \sin \alpha) \mathrm{d} ; 4 \mathrm{~d}]$ \\
$\mathrm{a}_{3, \mathrm{~s}}$ (unloaded end) & $150^{\circ} \leq \alpha \leq 210^{\circ}$ & $4 \mathrm{~d}$ \\
& $210^{\circ} \leq \alpha \leq 270^{\circ}$ & $\max [(1+6 \sin \alpha) \mathrm{d} ; 4 \mathrm{~d}]$ \\
& $0^{\circ} \leq \alpha \leq 180^{\circ}$ & $\max [(2+2 \sin \alpha) \mathrm{d} ; 3 \mathrm{~d}]$ \\
a4,1 (loaded edge) & $180^{\circ} \leq \alpha \leq 360^{\circ}$ & $3 \mathrm{~d}$ \\
\hline $\mathrm{a}_{4, \mathrm{c}}$ (unloaded edge) & & \\
\hline
\end{tabular}

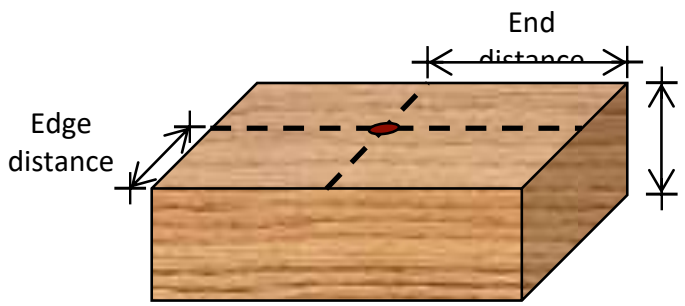

(a)

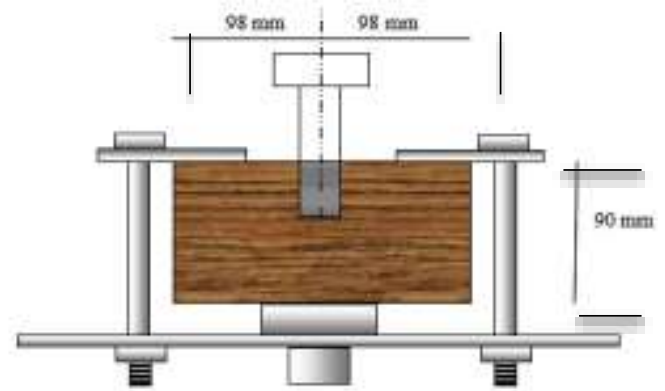

(b)

Fig. 2: Configuration of spacing and bolt insertion: (a) position of end and edge distance

(b) minimum dimensions and threaded bolt insertion in sample

According to EC5 Clause 4. 3-2, the bolt washer thickness has to be more than $0.3 \mathrm{~d}$, where $\mathrm{d}$ refers to the diameter of the bolt Steel plates with end-loaded four bolts held the samples for testing. Two washers each provided for bolt and nut. Fig. 3 shows the drilling process was on the blocks with glue line, exactly at the center of the block sample. Fig. 4 shows the bolts was manually threaded, however, at a certain stage of the bolt inserting, the bolt rotation become hard to turn by hand, especially for $18 \mathrm{~mm}$ diameter, thus the compressor machine is required to help to insert the remaining length of the threaded part of the bolt. While Fig. 5 shows the steel plate holder that was used to hold the block and Fig. 6 shows the total threaded samples. Fig. 7 shows the bolt inserted into the cylinder slot for the pulling process and Fig. 8 shows the withdrawal testing configurations for the block sample. 


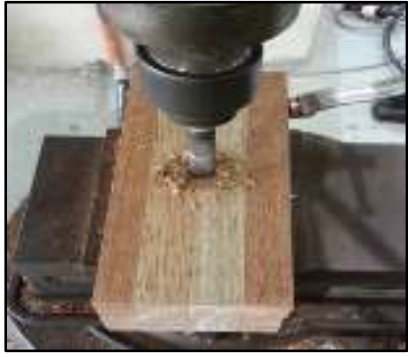

Fig. 3: Sample drilled

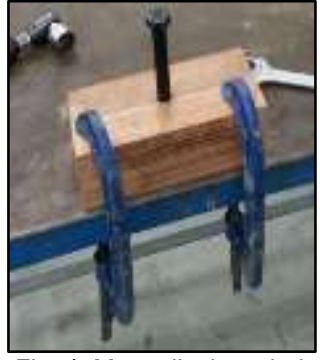

Fig. 4: Manually threaded

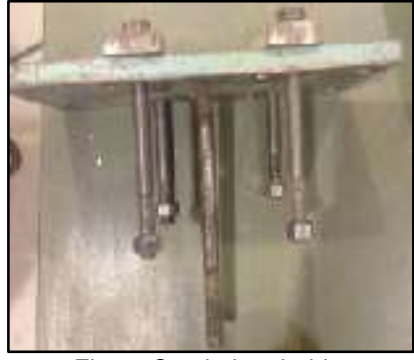

Fig. 5: Steel plate holder

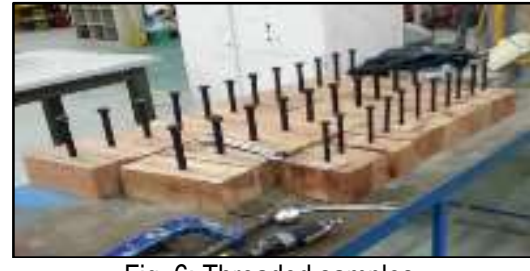

Fig. 6: Threaded samples

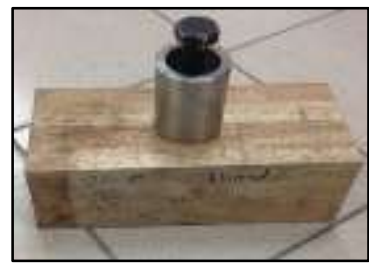

Fig. 7: Bolt inserted into the cylinder slot

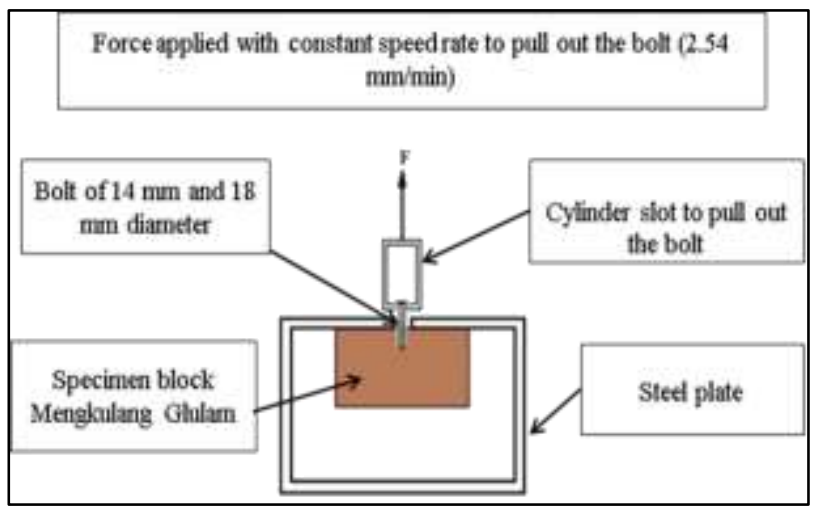

Fig. 8: Withdrawal testing configuration

The Experiment started with the smaller diameter $14 \mathrm{~mm}$ with the glue line, followed by the $14 \mathrm{~mm}$ without the glue line. The same processes were repeated for the $18 \mathrm{~mm}$ diameter bolts. The sample inserted with the bolt on top of the block was placed on the flat steel base plate in the Universal Testing Machine, as shown in Fig. 9.

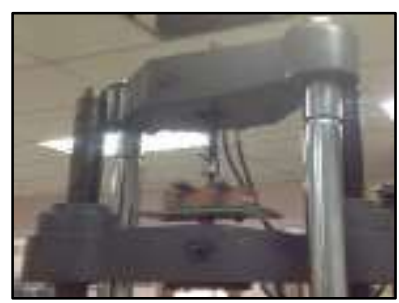

Fig. 9: Withdrawal test setup using UTM

The bolt fastener was pulled from the timber block sample at a uniform speed rate set at a constant of $2.54 \mathrm{~mm} / \mathrm{min}$ of pulling force. The test was run until the maximum load was accomplished and the complete failure of samples.

The withdrawal capacity, strength, and resistance formulas are equations 1, 2 and 3, respectively.

where;

$$
\text { fax }, R k=\text { fax.d.tpen }
$$

fax,Rk - withdrawal capacity $(\mathrm{kN})$

fax - withdrawal strength $\left(\mathrm{kN} / \mathrm{mm}^{2}\right)$

d $\quad$ - bolt diameter $(\mathrm{mm})$

tpen - treaded length of bolt $(\mathrm{mm})$

$$
\text { fax }=P / A
$$


where;

fax - withdrawal strength $\left(\mathrm{kN} / \mathrm{mm}^{2}\right)$

$P \quad-\operatorname{load}(\mathrm{kN})$

A $\quad$ - contact area of bolt and timber $\left(\mathrm{mm}^{2}\right)$

where;

W - withdrawal resistance $(\mathrm{kN} / \mathrm{mm})$

P $\quad-$ Load $(k N)$

tpen - threaded length of bolt $(\mathrm{mm})$

\subsection{Result and Discussion}

The bolts withdrawal capacities for this research were calculated by taking the average withdrawal capacity from all samples tested. The test samples were conducted with $14 \mathrm{~mm}$ and $18 \mathrm{~mm}$ bolt diameters, with varying points of drilling parallel with the glue line and parallel without the glue line. The maximum load, withdrawal capacity and withdrawal resistance of the Mengkulang glulam for $14 \mathrm{~mm}$ and $18 \mathrm{~mm}$ bolts pull-out in the condition with and without glue line are summarized in Tables 2 and 3 .

Table 2: Maximum load, withdrawal capacity and withdrawal resistance for $14 \mathrm{~mm}$ bolt diameter

\begin{tabular}{|c|c|c|c|c|c|c|}
\hline \multirow{2}{*}{ Specimen No. } & \multicolumn{2}{|c|}{ Max. Load } & \multicolumn{2}{c|}{ Withdrawal Capacity } & \multicolumn{2}{c|}{ Withdrawal Resistance } \\
\cline { 2 - 7 } & With glue & Without glue & With glue & Without glue & With glue & Without glue \\
\cline { 2 - 7 } & \multicolumn{2}{|c|}{$\mathrm{kN}$} & \multicolumn{2}{|c|}{$\mathrm{kN}$} & \multicolumn{2}{c|}{$\mathrm{kN} / \mathrm{mm}$} \\
\hline 1 & 1.24 & 9.807 & 0.37 & 2.90 & 0.03 & 0.22 \\
\hline 2 & 9.20 & 6.992 & 2.72 & 2.07 & 0.02 & 0.16 \\
\hline 3 & 7.31 & 6.862 & 2.16 & 2.03 & 0.16 & 0.15 \\
\hline 4 & 1.48 & 4.992 & 0.44 & 1.47 & 0.03 & 0.11 \\
\hline 5 & 7.13 & 9.169 & 2.10 & 2.71 & 0.16 & 0.20 \\
\hline Average & 5.27 & 7.564 & 1.56 & 2.23 & 0.08 & 0.17 \\
\hline St Dev. & 3.66 & 1.939 & 1.08 & 0.57 & 0.07 & 0.04 \\
\hline CoV & $69.44 \%$ & $25.63 \%$ & $69.46 \%$ & $25.63 \%$ & $91.16 \%$ & $25.65 \%$ \\
\hline
\end{tabular}

Table 3: Maximum load, withdrawal capacity and withdrawal resistance for $18 \mathrm{~mm}$ bolt diameter

\begin{tabular}{|c|c|c|c|c|c|c|}
\hline \multirow{2}{*}{ Specimen No. } & \multicolumn{2}{|c|}{ Max. Load } & \multicolumn{2}{c|}{ Withdrawal Capacity } & \multicolumn{2}{c|}{ Withdrawal Resistance } \\
\cline { 2 - 8 } & With glue & Without glue & With glue & Without glue & With glue & Without glue \\
\cline { 2 - 8 } & \multicolumn{2}{|c|}{$\mathrm{kN}$} & \multicolumn{2}{|c|}{$\mathrm{kN}$} & \multicolumn{2}{c|}{$\mathrm{kN} / \mathrm{mm}$} \\
\hline 1 & 19.11 & 13.042 & 4.30 & 2.94 & 0.42 & 0.29 \\
\hline 2 & 20.70 & 14.958 & 4.66 & 3.37 & 0.46 & 0.33 \\
\hline 3 & 21.13 & 15.606 & 4.88 & 3.51 & 0.47 & 0.35 \\
\hline 4 & 16.44 & 13.626 & 3.70 & 3.07 & 0.37 & 0.30 \\
\hline 5 & 15.31 & 15.378 & 3.45 & 3.46 & 0.34 & 0.34 \\
\hline Average & 18.54 & 14.522 & 4.20 & 3.27 & 0.41 & 0.32 \\
\hline St Dev & 2.57 & 1.128 & 0.61 & 0.25 & 0.06 & 0.03 \\
\hline CoV & $13.89 \%$ & $7.77 \%$ & $14.62 \%$ & $7.77 \%$ & $13.89 \%$ & $7.77 \%$ \\
\hline
\end{tabular}

In terms of load-carrying capacity between diameters, the maximum load $(\mathrm{kN})$ significantly increases when the diameter of the bolt increases. The maximum load-carrying capacities were also found to substantially increases when the withdrawal capacities increased. However, in comparison between with and without glue line, the connection with glue line for the $18 \mathrm{~mm}$ is the highest. Within the 14 $\mathrm{mm}$ load with glue line and without glue line, it is in contrast of bigger diameter with and without glue line. The $14 \mathrm{~mm}$ connections increase without the glue line, while the $18 \mathrm{~mm}$ load is found higher with the glue line. The typical patterns of failure for the load versus displacement of the connections are shown in Fig. 10 and Fig 11, respectively. 


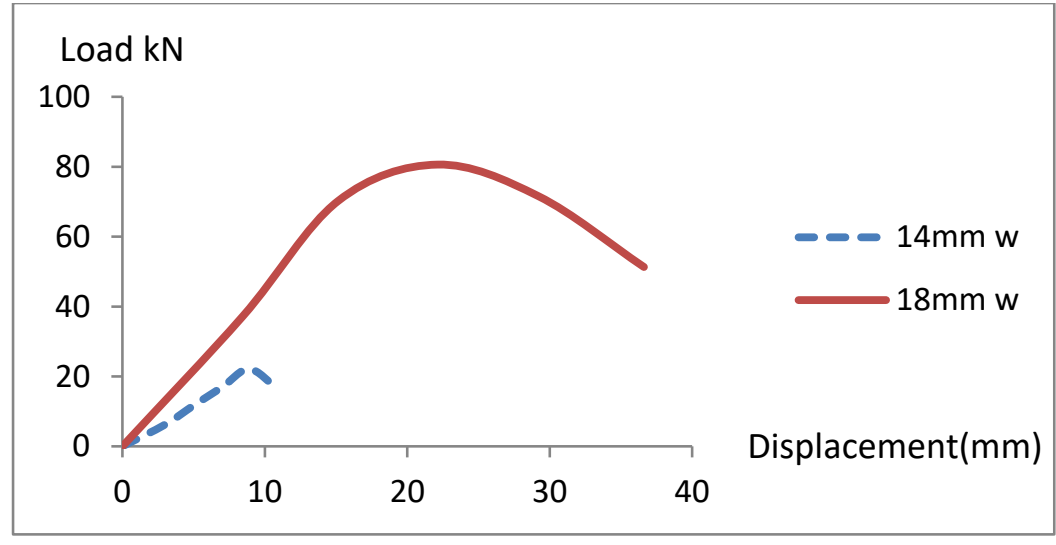

Fig. 10: Typical load versus displacement of $14 \mathrm{~mm}$ and $18 \mathrm{~mm}$ diameters with a glue line

Fig.11 shows the typical load-deformation graph for the withdrawal behaviour of both bolt connections. The linear pattern behaviour is shown by both connections at the earlier phase of the load increment. This increment possibly was because the threading from the bolt's rope effect prevents easily pulling out the bolt. In comparison, the $18 \mathrm{~mm}$ bolts connections were failed more ductile compared to $14 \mathrm{~mm}$ with a nearly brittle behaviour. The almost brittle behaviour in the smaller diameter was possibly due to the rope effect from the minor thread of the $14 \mathrm{~mm}$ bolt.

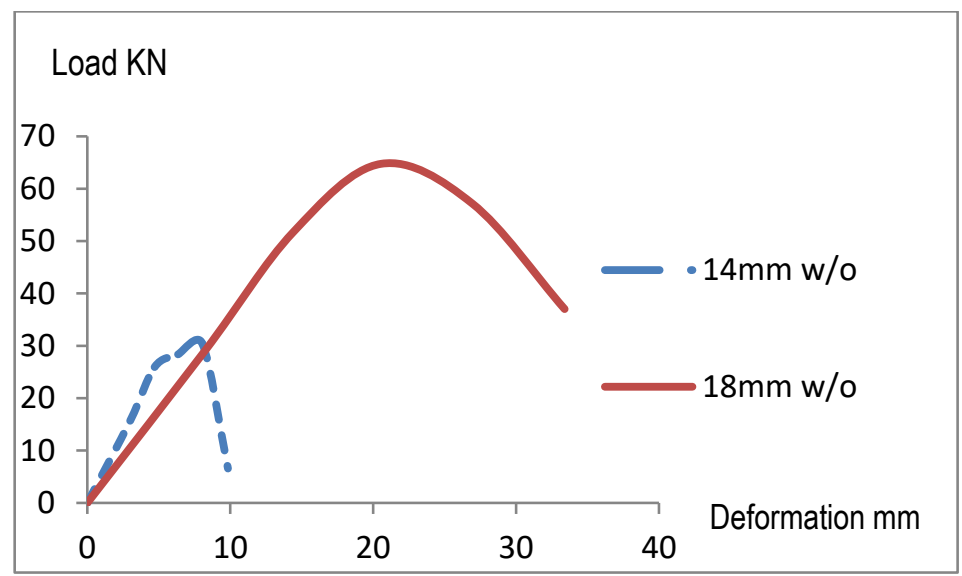

Fig. 11: Typical load versus displacement of $14 \mathrm{~mm}$ and $18 \mathrm{~mm}$ diameters without glue line

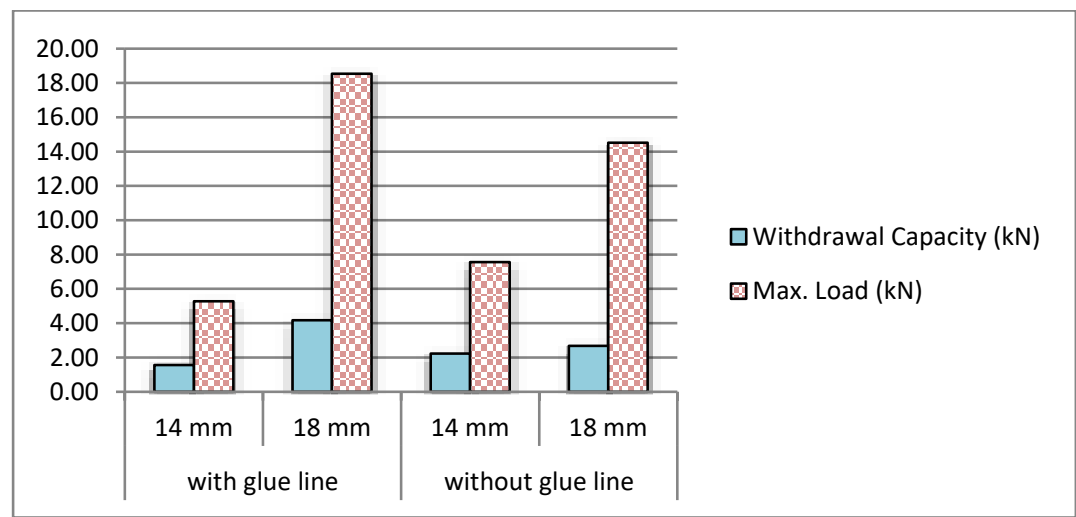

Fig. 12: Withdrawal resistance versus maximum load for both diameters

A similar pattern of behaviour was observed for connections without glue lines. Fig.11 shows the constant increment on every deformation of the sample. This possibility was because of the threading done on pre-drilling holes into the timber block samples. The grip, which played an essential role from the rope effect of threading part of the bolts, curbed the bolts to be pulled out readily. The deformations of the timber block sample are proceeding; more loads can be loaded until they accomplish the maximum load. The length of the threaded part of the bolt gripped inside the bolt pre-drilling hole became lower, making it easier to pull out the bolt from the timber block sample. Therefore, after the maximum load is accomplished, the load will drop at the same speed as the manner at the initial. 
The withdrawal capacity is compared with the maximum load (Fig. 12). Both were having a similar trend, and significantly the withdrawal capacity will increase once the load increases.

In terms of load-carrying capacity between diameters, the maximum load $(\mathrm{kN})$ significantly increases when the diameter of the bolt increases. The maximum load-carrying capacities are also found to substantially increases when the withdrawal capacities increase. However, compared with and without glue line, the connection with glue line for the $18 \mathrm{~mm}$ is the highest. Within the $14 \mathrm{~mm}$ load with glue line and without glue line, it is in contrast of bigger diameter with and without glue line. The $14 \mathrm{~mm}$ connections increase without the glue line, while the $18 \mathrm{~mm}$ load is found higher with the glue line.

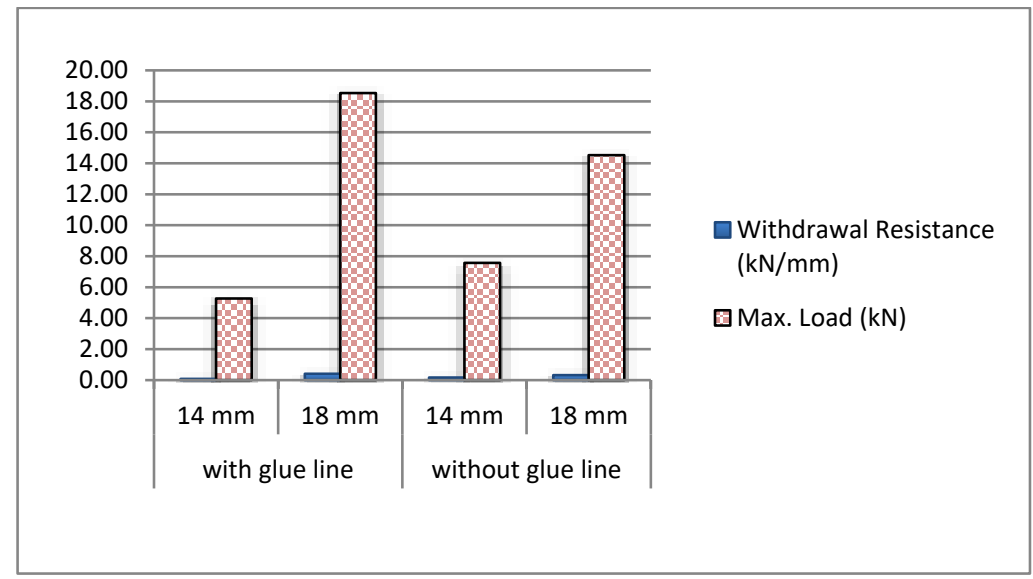

Fig. 13: Withdrawal resistance versus maximum load for both diameters

Withdrawal resistance for 14 and $18 \mathrm{~mm}$ diameter dowels in comparison with maximum load is shown in Fig. 13. A higher maximum load will contribute to a higher value of resistance. However, the value of resistance was minimal compared to the load capacity.

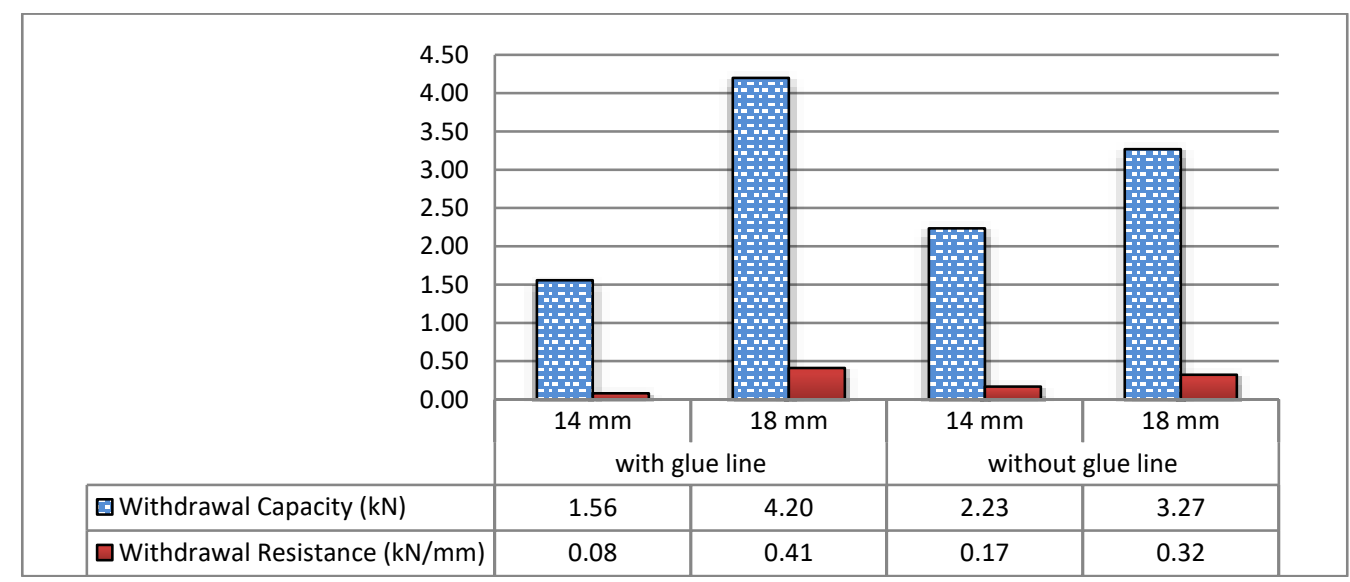

Fig. 14: Comparison of withdrawal capacity and the withdrawal resistance

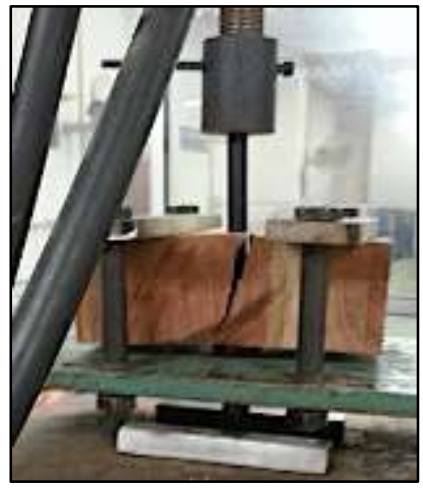

Fig. 15: Typical splitting for parallel with and without the glue line 
Fig.14 shows the bar and value comparison in detail between withdrawal capacity and withdrawal resistance. Among the highest differences in performance for average withdrawal capacity between $14 \mathrm{~mm}$ bolt diameter is the result of with to without the glue line with a percentage difference of $42.90 \%$. This result was because the tests conducted on all the samples showed a high coefficient of variant (CoV) (69.44\%) within the same test group. The high CoV could be affected by the manual preparation of the samples or the moisture content of the models at the time of the test. Little mistake in smaller diameter pre-drilled hole would affect more compared to larger diameter pre-drilled hole. From the high variance of the load-carrying capacity from the group of glue for $14 \mathrm{~mm}$ diameter connections, it is advisable to do more numbers specimens for the future test. While $14 \mathrm{~mm}$ parallel without the glue line shows minor splitting failure accordingly. It could be as well concluded that the smaller diameter will be affected more due to the glue line existence compared to without glue line. This indication shows sensibility to drill smaller size fastener in a parallel direction; without the glue line as it gives higher withdrawal resistance compared to the fastener parallel with the glue line. Fig. 15 shows the typical splitting for parallel with and without the glue line.

Table 4: Percentage difference between the withdrawal capacity and resistance between the two diameters

\begin{tabular}{clcc}
\hline $\begin{array}{c}\text { Type of } \\
\text { withdrawal }\end{array}$ & Comparison between parameter & Performance & $\begin{array}{c}\text { Percentage } \\
\text { (\%) }\end{array}$ \\
\hline & $14 \mathrm{~mm}$ to $14 \mathrm{~mm}$ (with to without) & Increase & 42.90 \\
$\begin{array}{c}\text { Withdrawal } \\
\text { Capacity (kN) }\end{array}$ & $18 \mathrm{~mm}$ to $18 \mathrm{~mm}$ (with to without) & Decrease & 22.14 \\
& $14 \mathrm{~mm}$ to $18 \mathrm{~mm}$ (with to with) & Increase & 169.23 \\
& $14 \mathrm{~mm}$ to $18 \mathrm{~mm}$ (without to without) & Increase & 46.63 \\
\hline $\begin{array}{c}\text { Withdrawal } \\
\text { Resistance } \\
(\mathrm{kN} / \mathrm{mm})\end{array}$ & $14 \mathrm{~mm}$ to $14 \mathrm{~mm}$ (with to without) & Increase & 112.50 \\
& $14 \mathrm{~mm}$ to $18 \mathrm{~mm}$ (with to without) $18 \mathrm{~mm}$ (with to with) & Decrease & 21.95 \\
& $14 \mathrm{~mm}$ to $18 \mathrm{~mm}$ (without to without) & Increase & 412.50 \\
\hline
\end{tabular}

Table 4 shows the percentage difference between the withdrawal capacities to the withdrawal resistance. Only the comparison between the $18 \mathrm{~mm}$ to $18 \mathrm{~mm}$ diameter with and without glue shows a decrease of $22.14 \%$ and $21.95 \%$ for both performances, accordingly. At the same time, the withdrawal resistance of $14 \mathrm{~mm}$ to $18 \mathrm{~mm}$ with glue for both connections shows the highest positive performances with $412.50 \%$ increment. It shows that the connection resistance with glue is much higher compared to the connection without glue. The adhesive has successfully contributed to a stronger bond between the steel bolt and the timber fibres for a bigger diameter. In this study, the smaller diameter was performed in contrast to the larger diameter for the resistance. The smaller diameter has stronger resistance without the glue line compared to with glue line. It can be concluded that the smaller diameter bolt has insignificantly affected by the glue line compared to the larger diameter of the bolt. Another possibility was due to the smaller area of glue that was directly contacted with the steel bolt, compared to the bigger area of glue in contact with the larger steel bolt. The glue contact area within the two bolt diameters has contributed to the different performance between the two tested connections.

\subsection{Conclusion}

In comparison between with and without glue line, the connection with glue line for the $18 \mathrm{~mm}$ is the highest. Within the $14 \mathrm{~mm}$ load with glue line and without glue line, it contrasts bigger diameter with and without glue line. The $14 \mathrm{~mm}$ connections increase without the glue line, while the $18 \mathrm{~mm}$ load is higher with the glue line. Therefore, it can be concluded that the larger bolt diameter provides the best withdrawal capacity, and the bolt performs well when it is inserted parallel with the glue line rather than parallel without the glue line. The smaller diameter affected more due to the glue line existence compared to without glue line. This indication shows sensibility to drill smaller size fastener in a parallel direction; without the glue line, it gives higher withdrawal resistance than the fastener parallel with the glue line. The smaller diameter bolt has insignificantly affected by the glue line compared to the larger diameter of the bolt. The glue contact area within the two bolt diameters has apparently contributed to the different performance between the two tested connections.

\section{Acknowledgements}

The authors gratefully acknowledge the help of the Universiti Teknologi MARA in providing the laboratory services and to SEGi University, Kota Damansara, for the project collaborations.

\section{References}

Abd. Malek, N.J.A., Hui, L. S. and Hassan, R. (2020). Performance of Withdrawal Capacity for Mengkulang Glulam Perpendicular to the Glue Line for $14 \mathrm{~mm}$ and $20 \mathrm{~mm}$ Bolt Diameter. International Journal of Innovative Technology and Exploring Engineering (IJITEE) ISSN: 2278-3075, Volume-9 Issue-3, January 2020 
Abd. Malek, N.J.A., Hassan, R., Kamari, S.N.S.M., Shakimon, M.N., Long, C.Y. (2016a). Performance comparison of bolt withdrawal capacity for Mengkulang glulam. Journal of Mechanical Engineering 2016, 13(2), pp. 113-124

Abd. Malek, N.J.A., Hassan, R., Hussin, T.A.R., Tern, N.D., Adam, C. (2016b). Perpendicular dowel-bearing strength properties without glue line for Mengkulang species. Journal of Mechanical Engineering 2016, 13(1), pp. 45-56

Abd. Malek, N.J.A, Al-Afif, A. A., Hassan, R. (2019). Shear Block Test Performance of Melunak and Mengkulang Parallel to Glueline. IOP Conference Series: Materials Science and Engineering 2019, 507(1), 012015

American Society for Testing and Materials (ASTM) D 1761- (2012). Standard Test Method for withdrawal capacity of Methods for Mechanical Fasteners in Wood. ASTM International - ASTM D1761-12. Standard Test Methods for Mechanical Fasteners in Wood.

BS EN 14080:2013. (2013). Timber structures — Glued laminated timber and glued solid timber - Requirements. June.

CIRAD Forestry Department. (2009). Mengkulang Species Classifications. https://www.cirad.fr/en

Eurocode 5. (2008). Design of Timber Structures (BS EN 1995-1-1-2004+A1:2008).

H'ng, P. S. (2003). Basic engineering properties of laminated veneer lumber (LVL) produced from tropical hardwood species. Unpublished. Universiti Putra Malaysia, Selangor, Malaysia.

Hamid, A., Halil, A., Shakri, A., Kamal, I., Azrieda, N., \& Zalifah, S. (2012). Screw Withdrawal Resistance of Moulded Laminated Veneer Oil Palm (MLVOP) Bonded with Formaldehyde Resins. Modern Applied Science, 112-119.

Hereford, B. (2012). Presentations: Structural Fasteners in Wood-to-Wood Connections. https://www.woodworks.org/wp-content/uploads/Hereford-structural-fastenerswood-to-wood-connections.pdf. Retrieved 11.9.2021.

Marutzky, P. D. (2002). Glue-laminated timber: a high-grade, ecologically sound material with favorable disposal properties. Fraunhofer-Institut for Wood Research,Wilhelm-Klauditz-Institute, Braunschweig , 1.

MS 758: 2001, Glued Laminated Timber - Performance Requirements and Minimum Production Requirements (First Revision). Malaysian Standard

Mohamad, W.N.N., Suliman, N.H., Kamarudin, M.K., Mohd-Amin, N., Hassan, R. (2018). Pull-out strength of steel rods bonded into mengkulang (tarrietia javanica) glulam at five different angles to the grain. Journal of Tropical Forest Science 2018, 30(1), pp. 67-74

Moody, R. C., \& Hernandez, R. (1997). Glued-laminated timber. Forest Product Laboratory. USDA Forest Service. Madison, Winconsin. n.d. Manufacturing process of glulam. http://www.plywoodinspection.com/manufacturing-process-of-glulam/ Retrieved 9.9.2021

Schuttner, S. (1997). Building and Designing Decks. United States: The Taunton Press. 